\title{
PENGADAAN BARANG DAN JASA DALAM RANGKA PERCEPATAN PENANGANAN COVID-19
}

\section{Deby Triasti}

Universitas Narotama (UN) Surabaya Jawa Timur, Indonesia

Email: debitriasti30@gmail.com

\section{Abstract}

Emergency procedures are simple and different from direct appointment, the Budget User (PA) instructs the PPK to appoint providers to carry out work based on the PA's requirements for handling Covid-19. PA in the APBN is the minister or head of the institution while in the APBD structure, $P A$ is the head of the region ie the governor or regent or mayor. Providers are used to providing the needs of the work unit concerned but must be ensured that there is no KKN, for example through mark ups, kickbacks, bribes or promises to provide other work in the future which is detrimental to the country's finances. Minister of Finance Sri Mulyani Indrawati said that the procurement of goods and services for emergencies such as now is already regulated in LKPP Institution Regulation No. 13 of 2018 concerning Procurement of Goods / Services in Handling Emergency Situations. Many changes in the State Budget (APBN) as well as the direct appointment mechanism for Personal Protective Equipment (PPE), masks and hand sanitizers can cause an atmosphere of concern. Even with direct appointment there are still a few things related to the committee and that is part of accountability, but Presidential Instruction No. 4 of 2020 is what the most important and Presidential Regulation regarding the procurement of goods / services is unnecessary, another legal basis is sufficient to deal with this unusual situation.

Keywords: budget users for covid-19 handlers

\section{Abstrak}

Prosedur kondisi darurat secara sederhana dan berbeda dengan melalui penunjukkan langsung, Pengguna Anggaran (PA) memerintahkan PPK menunjuk penyedia melaksanakan pekerjaan berdasarkan kebutuhan PA untuk penanganan Covid-19. PA dalam APBN adalah menteri atau kepala lembaga sedangkan dalam struktur APBD, PA adalah kepala daerah yaitu gubernur atau bupati atau wali kota. Penyedianya yang biasa menyediakan kebutuhan unit kerja yang bersangkutan namun harus dipastikan tidak adaKorupsi, Kolusi, Nepotisme(KKN) misalnya melalui mark up, kick back, suap atau pun janji memberikan pekerjaan lain di kemudian hari yang merugikan keuangan negara. Menteri Keuangan (Menkeu) Sri Mulyani Indrawati mengatakan bahwa pengadaan barang dan jasa untuk kondisi darurat seperti saat ini memang sudah diatur dalam Peraturan Lembaga Kebijakan Pengadaan Barang/Jasa Pemerintah(LKPP) Nomor 13 Tahun 2018 tentang Pengadaan Barang/Jasa Dalam Penanganan Keadaan Darurat.Banyaknya perubahan di dalam Anggaran Pendapatan dan Belanja Negara (APBN) serta adanya mekanisme penunjukan langsung untuk Alat Pelindung Diri (APD), masker dan hand sanitizer dapat menimbulkan suasana kekhawatiran.Meksipun dengan 
penunjukan langsung masih ada beberap hal beberapa terkait kominten dan itu bagian dari akuntabilitas, namun Inpres Nomor 4 Tahun 2020 itu yang terpenting dan Perpres mengenai pengadaan barang/jasa rasanya tidak perlu, sudah cukup landasan hukum lain untuk menghadapi situasi yang tidak biasa ini.

Kata Kunci: pengguna anggaran untuk penangan Covid-19

\section{Pendahuluan}

Di tengah keadaan darurat wabah virus corona atau Covid-19, pengadaan barang/jasa masih tetap diperbolehkan. Hal ini mengikuti Peraturan Lembaga Kebijakan Pengadaan Barang/Jasa Pemerintah (LKPP) Nomor 13/2018 tentang Pengadaan Barang/Jasa dalam penanganan keadaan darurat (Ramli, 2020).

Selain ketentuan dari LKPP, maka di dalam pengadaan barang/jasa kedaruratan untuk Covid-19 perlu memperhatikan beberapa ketentuan yang dijadikan dasar ketentuan seperti Undang-Undang RI Nomor 24 Tahun 2007 tentang Penanggulangan Bencana, Peraturan Pemerintah Nomor 22 Tahun 2008 tentang Pendanaan dan pengelolaan Bantuan Bencana, Peraturan Presiden Nomor 16 Tahun 2018 tentang Pengadaan barang/jasa Pemerintah, Instruksi Presiden Republik Indonesia nomor 4 Tahun 2020 tentang Refocussing kegiatan, Realokasi Anggaran serta Pengadaan barang/jasa dalam rangka percepatan penanganan Corona Virus Disease 2019 (COVID19) dan Keputusan Presiden Republik Indonesia Nomor 12 Tahun 2020 tentang Penetapan Bencana Non Alam Penyebaran Corona Virus Disease (Covid-19) sebagai bencana Nasional serta kete ntuan lainnya yang terkait dengan regulasi COVID-19 (Florentina, Wibowo, Hoesodo, Murti, \& Tangkas, 2020).

Pada tahap perencanaan pengadaan identifikasi kebutuhan barang/jasa, analisis ketersediaan sumber daya dan penetapan cara pengadaan adalah hal yang harus dilalui, kemudian di dalam pelaksanaan pengadaan barang/jasa dapat dengan cara swakelola atau menggunakan penyedia. Apabila pejabat pembuat komimen (PPK) menggunakan penyedia maka PPK menunjuk penyedia dan melakukan surat pesanan (SP) / surat perintah mulai kerja (SPMK), penyedia melaksanakan pekerjaan dan menyiapkan dokumen kewajaran harga guna pemeriksaan (audit), apabila melalui swakelola PPK melakukan koordinasi dengan pihak yang terlibat dalam penanganan darurat, melakukan pemeriksaan bersama dan rapat persiapan, pelaksaan pekerjaan dan serah terima pekerjaan (Hamidi, 2020). Untuk penyelesaian pembayaran melalui 3 tahap yakni kontrak, pembayaran dan post audit dimana aparat pengawas internal pemerintah (APIP) atau badan pengawasan keuangan dan pembangunan (BPKP) melakukan audit/pemeriksaan atas kewajaran harga yang ditawarkan oleh penyedia (Triasti, 2021).

Dalam hal pengadaan barang/jasa terkait penanganan keadaan darurat sumbersumber pendanaan itu berasal dariAnggaran Pendapatan dan Belanja Negara Indonesia (APBN) Anggaran K/L, termasuk refocusing, realokasi, anggaran cadangan yang dari APBD sumbernya pendapatan asli daerah (PAD)\& Revisi anggaran dan dana kas daerah serta sumber lain sesuai Perundang-undangan. Sehingga pengadaan dalam penanganan keadaan darurat dapat berupaya terbaik mencapai tujuan pengadaan dengan optimalkan 
mitigasi resiko yang memperhatikan aspek regulasi, justifikasi dan data dukung/dokumentasi berlandaskan prinsip dan etika pengadaan.

\section{Metode Penelitian}

Penelitian ini menggunakan metode studi kasus eksplorasi dan pendekatan penelitiannya menggunakan metode studi kasus kualitatif yang digunakan untuk mendapatkan informasi kendala dan akibat dari pandemi Covid-19 (Purwanto et al., 2020). Studi kasus eksplorasi merupakan metode yang disertai dengan pengumpulan data tambahan. Sedangkan pendekatan studi kasus kualitatif merupakan penelitian dan pemahaman yang berdasarkan pada metodologi yang menyelidiki suatu fenomena sosial dan masal

\section{Hasil dan Pembahasan}

Wabah Virus Corona (Covid-19) yang menyerang hampir seluruh negara di dunia membuat situasi ekonomi global mengalami perlambatan. Di Indonesia sendiri, beberapa sektor industri sudah merasakan dampak langsung dari penyebaran virus yang bermula di Kota Wuhan, China ini.Guna menekan dampak penyebaran virus Corona terhadap dunia usaha yang saat ini sudah mengkhawatirkan, pemerintah sudah menggelontorkan dua paket stimulus ekonomi. Dua paket kebijakan ini diproyeksikan untuk industri-indsutri tertentu yang dinilai berdampak langsung atas penyebaran virus Corona di Indonesia. Dalam rapat-rapat kabinet bersama Presiden Joko Widodo, Sri Mulyani menegaskan bahwa fokus kebijakan pemerintah ke depan adalah kesehatan dan perlindungan masyarakat terhadap wabah virus Corona (Mardiyah \& Nurwati, 2020).

Dalam konteks ini, lanjutnya, postur Anggaran Pendapatan dan Belanja Negara (APBN) untuk tahun 2020 dipastikan mengalami perubahan drastis. Seluruh perhitungan baik itu makro maupun mikro mengalami pergeseran yang sangat signifikan, seperti nilai tukar rupiah, target penerimaan pajak, target pertumbuhan ekonomi dan lain sebagainya, yang dipastikan tidak akan berjalan sesuai prediksi. Bahkan pemerintah 'dipaksa' melakukan perubahan dalam pos-pos anggaran demi pencegahan penyebaran virus Corona di Indonesia. Atas dasar itu pula, pemerintah akan segera melakukan perubahan APBN. Tentunya, kata Sri Mulyani, perubahan APBN membutuhkan landasan hukum baru, baik dalam bentuk Perppu atau mungkin undangundang. Salah satunya adalah rencana relaksasi defisit APBN menjadi 5 persen karena negara dinilai dalam kondisi kegentingan yang memaksa. Hal ini sesuai dengan UU No. 17 Tahun 2003 tentang Keuangan Negara.

Sekarang dibahas bersama DPR bagaimana mekanisme (pelebaran defisit) dalam kondisi mendesak. Ini situasi kegentingan memaksa makanya Bapak Presiden menyampaikan bahwa pemerintah bisa memberikan perppu menyangkut perubahan APBN sendiri. Perppu ataukah UU nanti Presiden yang menentukan, Meski demikian, relaksasi defisit yang melewati 3 persen tetap harus dilakukan secara bertanggung jawab dan prudent.

Selain pelebaran defisit APBN, untuk menjalankan stimulus ekonomi jilid 3 yang saat ini tengah dibahas, Sri Mulyani mengaku pemerintah juga akan mengeluarkan 
beberapa landasan hukum baru. Hal ini bertujuan agar seluruh kebijakan yang diterbitkan masih sesuai dengan koridor APBN dan keuangan negara. Kebijakan yang diambil bersifat jangka pendek yakni 3-6 bulan.

Waktu melakukan perubahan realokasi anggaran antar kementerian, itu semuanya mendapatkan landasan hukum yang baik walaupun situasi genting. Kalau lebih dari ini seperti paket ketiga, kemungkinan kita akan membutuhkan landasan hukum berbeda. Kalau pajak, bea masuk dan penundaan, itu cuma penerimaan, tapi kalau sampai memberikan jamjnan kepada lembaga keuangan agar tetap bisa menyalurkan kredit dan relaksasi, ini bentuknya akan berbeda. Usaha pemerintah dalam melakukan percepatan penanganan COVID-19sebagai berikut,

1. Melakukan identifikasi terkait kebutuhan yang diperlukan oleh masyarakat dalam situasi pandemic Covid-19 pasca penerbitan Instruksi Presiden (Inpres) Nomor 4 Tahun 2020 tentang Refocussing Kegiatan, Realokasi Anggaran, serta Pengadaan Barang dan Jasa Dalam Rangka Percepatan Penanganan Corona Virus Disease 2019 (Covid-19) (Manao, 2020).

2. Mengakomodasikan kebutuhan yang sifatnya emergency baik sektor kesehatan dan social safety net. Apakah meng-cover di luar $\mathrm{PKH}$, bagaimana caranya dihitung, akan di cover, dan mengindentifikasi kebutuhan perusahaan. Peket jilid 2 untuk industri manufaktur, nah di jilid 3 sektor industri transportasi dan perhotelan juga akan diberikan insentif dan dimasukkan di dalam paket sama seperti manufaktur. Ini akan mempengatuhi penerimaan negara tahun ini, dan kita inventarisasi dan respon sesegera mungkin.

Kepala Badan Nasional Penanggulangan Bencana (BNPB), Letjend TNI, Ketua Gugus Tugas Percepatan Penanganan Virus Korona (Covid-19) menyampaikan bahwa dalam Rapat Terbatas (ratas), sebanyak 34 Gubernur mendukung keputusan pemerintah dalam mengambil kebijakan, yaitu social distancing yang oleh Presiden Joko Widodo (Jokowi) diterjemahkan menjadi physical distancing.

Rangkuman arahan Presiden kepada para Gubernur terkait penanganan Covid-19 yang disampaikan Kepala BNPB adalah sebagai berikut,

1. Presiden menekankan physical distancing yang bisa diterjemahkan oleh para Gubernur termasuk seluruh pejabat yang ada di daerah dengan jaga jarak atau jaga jarak aman dan disiplin untuk melaksanakannya.

2. Presiden menegaskan dan menekankan kepada para Gubernur bahwa penjelasanpenjelasan ini harus sampai ke tingkat yang paling rendah, yaitu desa dan kelurahan

3. Setiap pejabat di daerah, harus dapat menerjemahkan tentang ancaman yang semakin serius dari wabah Korona ini dan bagaimana caranya agar semua bisa selamat.

4. Presiden meminta agar masyarakat tidak panik, saling berbagi pengalaman, saling berbagi cerita yang bisa memberikan semangat agar bisa terhindar dari wabah ini.

5. Presiden menekankan prioritas untuk penggunaan Rapid Test ditujukan kepada pekerja medis, karena mereka lah orang yang paling rentan, yang paling terdepan, dan yang berpeluang akan terpapar.

6. Presiden telah menegaskan seluruh industri tekstil harus memprioritaskan kebutuhan domestik dulu. 
7. Gubernur untuk bisa bekerja sama dengan Pangdam dan Kapolda supaya apabila APD tiba, sesegera mungkin didistribusikan ke rumah sakit-rumah sakit yang memerlukan karena pengalaman mulai dari kemarin dan juga sampai dengan dini hari tadi ternyata masih ada rumah sakit yang belum mendapatkan APD padahal provinsinya telah didistribusikan.

8. Upayakan semaksimal mungkin masyarakat yang masih sehat untuk menjaga kesehatan dirinya. Ia meminta jangan anggap enteng, jangan anggap sepele prosedur protokol, ketentuan yang berhubungan dengan pencegahan hendaknya betul-betul ditaati.

9. Penegakan hukum ke depan harus menjadi prioritas, karena Gubernur sesuai dengan Keppres Nomor 7 Tahun 2020 memiliki kewenangan untuk memberikan penegakan hukum dengan memanfaatkan aparat yang ada.

10. Presiden memerintahkan kepada para Gubernur untuk membuat rencana aksi yang detail, khususnya yang berhubungan dengan peta kesadaran Covid-19 di wilayah masing-masing.

11. Semua kebijakan yang diambil oleh para Gubernur selaku Ketua Gugus Tugas diupayakan harus komprehensif, harus holistik melibatkan segenap komponen yang ada, termasuk tokoh-tokoh masyarakat, tokoh agama, dan tokoh-tokoh lainnya.

12. Sampai dengan jam 11.00 tentang Wisma Atlet, terdapat 102 orang pasien yang mendaftar mulai kemarin sore, kemudian yang dirawat sebanyak 71 orang dan 2 di jadwalkan akan dikirim ke RSPAD karena kondisisnya kurang begitu baik.

Pengadaan Barang/Jasa Pemerintah dalam rangka penanganan keadaan darurat Covid-19 dilakukan sebagai berikut:

1. Menteri, Pimpinan Lembaga dan Kepala Daerah mengambil langkah-langkah lebih lanjut dalam rangka Percepatan Pengadaan Barang/Jasa Penanganan Darurat dalam rangka penanganan Covid-19.

2. Pengguna Anggaran (PA) atau Kuasa Pengguna Anggaran (KPA) menetapkan kebutuhan barang/jasa dalam rangka penanganan darurat untuk penanganan Covid19 dan memerintahkan Pejabat Pembuat Komitmen (PPK) untuk melaksanakan Pengadaan Barang/Jasa.

3. PPK melaksanakan langkah-langkah sebagai berikut:

a. Menunjuk Penyedia yang antara lain pernah menyediakan barang/jasa sejenis di instansi pemerintah atau sebagai Penyedia dalam Katalog Elektronik. Penunjukan Penyedia dimaksud dilakukan walaupun harga perkiraannya belum dapat ditentukan (Arifin, 2019).

b. Untuk pengadaan barang, menerbitkan Surat Pesanan yang disetujui oleh Penyedia, meminta Penyedia menyiapkan bukti kewajaran harga barang, dan melakukan pembayaran berdasarkan barang yang diterima. Pembayaran dapat dilakukan dengan uang muka atau setelah barang diterima (termin atau seluruhnya).

c. Untuk pengadaan pekerjaan konstruksi/jasa lainnyaljasa konsultansi, menerbitkan Surat Penunjukan Penyedia Barang/Jasa (SPPBJ) dan Surat Perintah Mulai Kerja (SPMK), meminta Penyedia menyiapkan bukti kewajaran 
harga, menandatangani Kontrak dengan Penyedia berdasarkan Berita Acara Perhitungan Bersama dan Berita Acara Serah Terima Hasil Pekerjaan, dan melakukan pembayaran berdasarkan SPPBJ. Pembayaran dapat dilakukan dengan uang muka atau setelah pekerjaan selesai (termin atau seluruhnya).

d. untuk pengadaan Barang, Jasa Lainnya dan Pekerjaan Konstruksi diutamakan menggunakan jenis Kontrak Harga Satuan.

4. Pengadaan barang/jasa untuk penanganan darurat dalam rangka penanganan Covid19 juga dapat dilaksanakan dengan swakelola.

5. Untuk memastikan kewajaran harga setelah dilakukan pembayaran, PPK meminta audit oleh Aparat Pengawas Intern Pemerintah atau Badan Pengawasan Keuangan dan Pembangunan.

6. Para pihak yang terlibat dalam pengadaan ini wajib mematuhi etika pengadaan dengan tidak menerima, tidak menawarkan atau tidak menjanjikan untuk memberi atau menerima hadiah, imbalan, komisi, rabat dan berupa apa saja dari atau kepada siapa pun yang diketahui atau patut diduga berkaitan dengan pengadaan barang/jasa ini.

7. Kementerian/Lembaga/Pemerintah Daerah dapat berkonsultasi lebih lanjut denganLembaga Kebijakan Pengadaan Barang/Jasa Pemerintah (LKPP). Konsultasi dapat dilakukan melalui narahubung yang tersedia di alamat www.lkpp.go.id. LKPP mengambil langkah strategis dengan menggunakan prosedur pengadaan barang dan jasa dalam kondisi darurat dilaksanakan secara sederhana dan berbeda, dengan melalui penunjukan langsung sebagai Perpres Nomor 16 Tahun 2018 dan Peraturan LKPP Nomor 13 Tahun 2018

INPRES Nomor 4/2020 juga memberikan wewenang kepada Kementerian Dalam Negeri untuk mengambil langkah-langkah lebih lanjut dalam rangka percepatan penggunaan Anggaran Pendapatan dan Belanja Daerah (APBD) dan/atau perubahan peraturan kepala daerah tentang penjabaran APBD untuk percepatan penanganan Corona Virus Disease 2019 (COVID-19) kepada Gubernur/Bupati/Walikota (Hamidi, 2020). Sebagai bentuk tindak lanjut, Kementerian Dalam Negeri merumuskan aturan dalam dalam rangka percepatan penggunaan Anggaran Pendapatan dan Belanja Daerah (APBD) dan/atau perubahan peraturan kepala Daerah tentang penjabaran APBD untuk percepatan penanganan COVID-19 melalui Permendagri nomor 20 tahun 2020 dan dipertegas kembali kepada Pemerintah Daerah melalui Surat Edaran Nomor 440/2436/SJ tentang Pencegahan Penyebaran Corona Virus Disease 2019 (COVID-19) di lingkungan Pemerintah Daerah tanggal 17 Maret 2020. Hal ini telah sejalan dengan Instruksi Presiden Nomor 4 Tahun 2020 tentang Refocussing Kegiatan (Harefa, 2021). Realokasi Anggaran, serta Pengadaan Barang dan Jasa Dalam Rangka Percepatan Penanganan Corona Virus Disease 2019 (COVID-19).

A. Protokol pencegahan covid-19 dalam penyelenggara jasa konstruksi

a. Skema Protokol Pencegahan Covid-19 Dalam Penyelenggaran Jasa Konstruksi

1. Pembentukan Satuan Tugas (Satgas) Pencegahan Covid-19 
a. Pengguna Jasa dan Penyedia Jasa wajib membentuk Satgas Pencegahan Covid-19 yang menjad bagian dari Unit Keselamatan Konstruksi

b. Satgas Pencegahan Covid-19 sebagaimana dimaksud pada huruf a dibentuk oleh Pejabat Pembuat Komitmen (PPK) tersebut

c. Satgas Pencegahan Covid-19 sebagaimana dimaksud pada huruf a berjumlah paling sedikit 5 orang yang terdiri atas;

2. 1(satu) Ketua Merangkap Anggota; dan

3. 4(empat) Anggota yang mewakili Pengguna Jasa dan Penyedia Jasa

4. Satgas Pencegahan Covid-19 memiliki tugas, tanggung jawab, dan kewenangan untuk melakukan;

1) Sosialisasi

2) Pembelajaran (Edukasi)

3) Promosi Teknik

4) Metode / Pelaksanaan pencegahan Covid-19 Kementerian PUPR melakukan Identifikasi Potensi Bahaya Covid-19 di lapangan

5) Berkoordinasi dengan Satgas Penanggulangan Covid-19 Kementerian PUPR melakukan identifikasi Potensi Bahaya Covid-19 di lapangan

6) Pemeriksaan Kesehatan terkait potensi terifeksi Covid-19 kepada semua pekerja dan tamu proyek

7) Pemantauan kondisi kesehatan pekerja dan pengendalian mobilisasi / demobilisasi pekerja

8) Pemberian Vitamin dan Nutrisi tambahan guna peningkatan imunitas tubuh

9) Pengadaan Fasilitas Kesehatan di lapangan

10) Melaporkan kepada PPK dalam hal telah ditemukan pekerja positif dan / atau berstatus Pasien Dalam Pengawasan (PDP) dan merekomendasikan dilakukan penghentian kegiatan sementara

5. Identifikasi Potensi bahayaa Covid-19 di Lapangan

A. Satgas pencegahan Covid-19 berkoordinasi dengan Satgas Penanggulangan Covid -19 Kementerian PUPR untuk memutuskan;

1) Identifikasi potensi resiko lokasi proyek terhadap pusat sebaran penyebaran covid -19 di daerah yang bersangkutan

2) Kesesuaian fasilitas kesehatan di lapangan dengan protokol penanganan Covid-19 yang dikeluarkan oleh pemerintah

3) Tindak lanjut terhadap Penyelenggaraan Jasa Konstruksi

B. Dalam hal Penyelenggaraan Jasa Konstruksi tersebut teridentifikasi;

1) Memiliki resiko tinggi akibat lokasi proyek berada di pusat sebaran

2) Telah ditemukan pekerja yang positif dan / atau berstatus Pasien Dalam Pengawasan (PDP); atau

3) Pimpinan Kementerian/lembaga/instansi/kepala daerah telah mengeluarkan peraturan untuk menghentikan kegiatan sementara akibat keadaan 
C. Penghentian penyelenggaran jasa konstruksi sebagaimana dimaksud diatas dilakukan sesuai ketentuan yang tidak dapat terpisahkan dari intsruksi pemerintah.

D. Dalam Hal penyelenggaraan jasa konstruksi tersebut karena sifat dan urgensinya tetap harus dilaksanakan sebagai bagian dari penanganan dampak sosial dan ekonomi dari Covid-19, maka penyelenggaran jasa konstruksi tersebut dapat diteruskan dengan kententuan;

1) Mendapat persetujuan dari Menteri Pekerjaan Umum dan Perumahan Rakyat;

2) Melaksanakan protokol pencegahan Covid-19 dengan disiplin tinggi dan dilaporkan secara berkala oleh satga pencegahan covid19.

3) Penyediaan fasilitas kesehatan di lapangan

a. Penyedia Jasa Pekerjaan Konstruksi Wajib menyediakan ruang klini kesehatan di lapangan yang dilengkapi dengan sarana kesehatan yang memadai, antara lain tabung oksigen, pengukur suhu badan, pengukur tekanan darah, obat-obatan dan petugas medis

b. Penyedia Jasa Pekerjaan Konstruksi Wajib memiliki kerja sama operasional perlindungan kesehatan dan pencegahan covid-19 dengan rumah sakit dan / atau pusat kesehatan masyarakat terdekat untuk tindakan darutat

c. Penyedia Jasa Pekerjaan Konstruksi Wajib menyediakan fasilitas tambahan antara lain; pencuci tangan, masker dikantor dan lapangan bagi semua pekerja dan tamu

d. Penyedia Jasa Pekerjaan Konstruksi Wajib menyediakan vitamin dan nutrisi tambahan bagi pekerja dalam meningkatkan imunitas tubuh

4) Pelaksanaan Pencegahan Covid-19 di lapangan

a. Satgas pencegahan Covid-19 bersama petugas medis harus menyampaikan penjelasan, anjuran, kampanye, promosi teknik pencegahan Covid-19 dalam setiap kegiatan penyuluhan

b. Petugas medis bersama satuan pengamanan melaksanakan pengukuran suhu tubuh kepada seluruh pekerja dan karyawan

c. Satgas Pencegahan Covid-19 harus melakukan tindakan apabila ada pekerja yang memiliki suhu tubuh diatas suhu tubuh normal 38 derajat celcius

d. Petugas medis dibantu tim satgas melakukan evaluasi dan penyemprotan disinfektan pada seluruh tempat, fasilitas, dan peralatan kerja

e. Penghentian sementara dilakukan hingga proses evaluasi dan penyemprotan disinfektan, serta pelaksanaan pemeriksaan kesehatan dan isolasi tenaga kerja yang pernah melakukan kontak fisik dengan tenaga kerja yang terpapar telah selesai 
B. Mekanisme pencegahan Covid-19 dalam penyelenggara jasa konstruksi

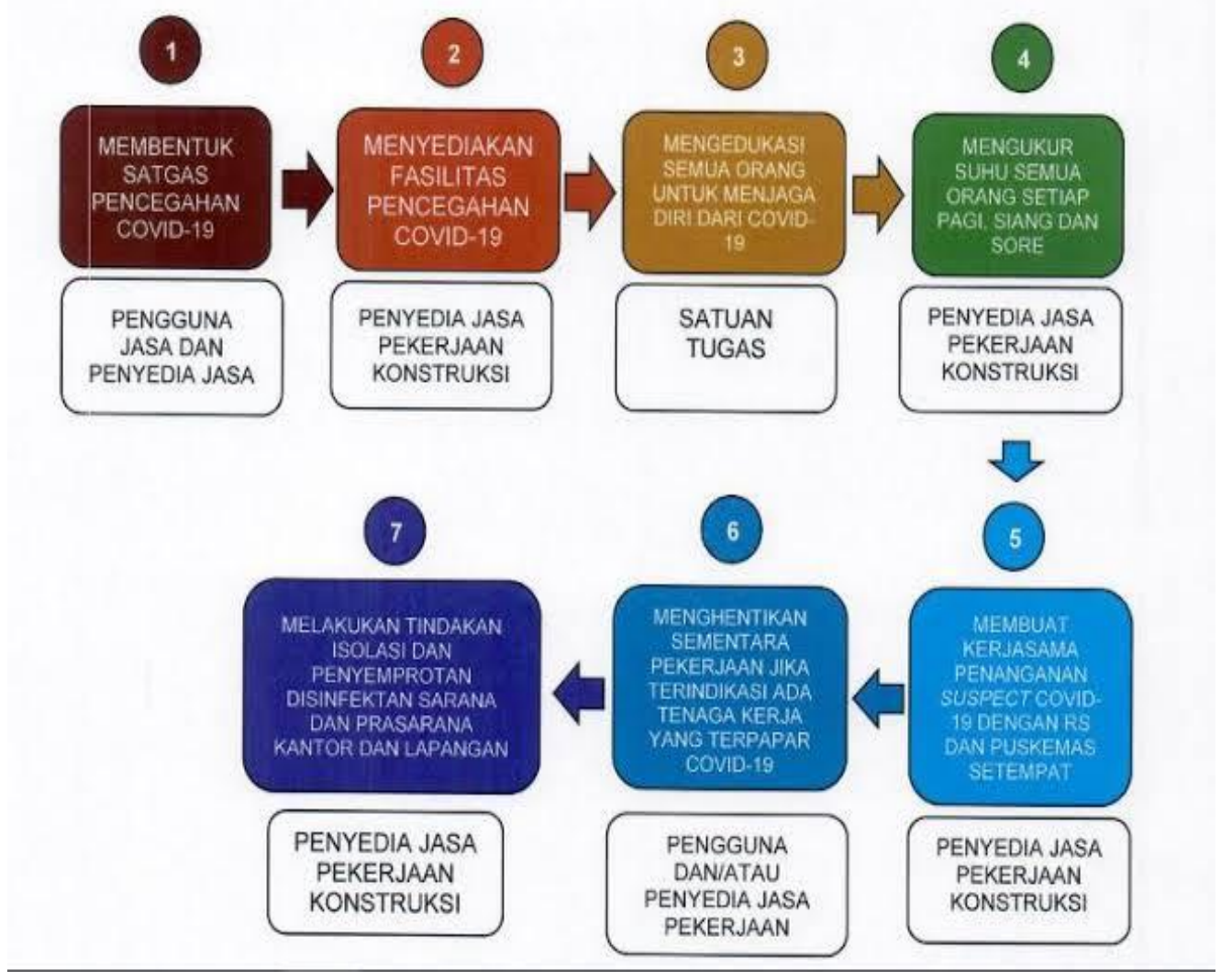

Perkembangan pandemik virus Covid-19 dan menindaklanjuti arahan presiden Republik Indonesia terkait upaya pencegahan Covid-19, diperlukan protokol pencegahan Covid-19 dalam penyelenggaraan jasa konstruksi bagi pengguna jasa dan penyedia jasa yang merupakan bagian dari keseluruhan kebijakan untuk mewujudkan keselamatan konstruksi termasuk keselamatan dan kesehatan kerja , keselamatan publik, dan keselamatan lingkungan pada setiap tahap penyelenggaraan jasa konstruksi (Sari, 2021).

C. Cegah Korupsi PBJ Penanganan Covid-19, KPK Beri Arahan Kepala Daerah

Komisi Pemberantasan Korupsi (KPK) berikan arahan perihal pengadaan barang dan jasa (PBJ), terkait kebutuhan bencana kepada seluruh kepala daerah guna penggunaan anggaran pelaksanaan $\mathrm{PBJ}$, dalam rangka percepatan penanganan pandemi virus Corona (Covid-19).

Arahan itu merujuk Surat Edaran KPK Nomor 08 Tahun 2020 yang di antaranya memuat rambu-rambu pencegahan korupsi untuk memberikan kepastian bagi pelaksana pengadaan (Rohman, 2013).

Hal itu disampaikan Ketua KPK Firli Bahuri kepada seluruh Sekretaris Daerah (Sekda) dan Bupati/Walikota dalam rapat koordinasi melalui konferensi video bersama Ketua BadanPemeriksa Keuangan Agung Firman, Menteri Dalam Negeri Tito Karnavian, Kepala Badan Pengawasan Keuangan dan Pembangunan (BPKP) Muhammad Yusuf Ateh, dan Kepala Lembaga Kebijakan Pengadaan Barang/Jasa 
Pemerintah (LKPP) Roni Dwi Susanto, di Gedung B Kemendagri, Rabu, 8 April 2020.

Pengadaan barang dan jasa terkait kebutuhan bencana merupakan tanggung jawab Pengguna Anggaran (PA), dan KPK minta tidak perlu ada ketakutan berlebihan sehingga menghambat penanganan bencana. Laksanakan pengadaan barang sesuai dengan ketentuan dan pendampingan oleh LKPP. Dalam kondisi darurat, pengadaan barang dan jasa boleh dilakukan dengan cara swakelola. Dengan syarat, selama terdapat kemampuan pelaksana swakelola (Rahmad Daulay, 2021).

Sesuai dengan SE yang telah dikeluarkan, SE tersebut ditujukan kepada Gugus Tugas di tingkat pusat dan daerah untuk memberikan panduan dalam proses PBJ dalam situasi darurat. Salah satu poinnya memuat rambu-rambu pencegahan korupsi untuk memberikan kepastian bagi pelaksana pengadaan.

KPK menyadari bahwa di tengah situasi darurat, harga barang/jasa terkait penanganan Covid-19 mengalami kenaikan signifikan, karena permintaan global yang meningkat dan produsen yang terbatas. Hal ini menyebabkan kondisi pasar tidak normal, maka diharapkan pelaksanaan anggaran dan PBJ dapat juga dilakukan dengan mengedepankan harga terbaik (value for money). PBJ dalam kondisi darurat cukup menekankan pada prinsip efektif, transparan, dan akuntabel. Misalnya, dengan cara mendokumentasikan dan membuka setiap tahapan pengadaan dalam rangka mencari harga terbaik atau value for money tersebut (Florentina et al., 2020).

Perpres No 16 Tahun 2018 tentang Pengadaan Barang/Jasa Pemerintah, menitikberatkan pada pemenuhan nilai manfaat yang sebesar-besarnya (value for money) dan tidak selalu dengan harga terendah. Sehingga pelaksanaan pembelanjaan anggaran pemerintah harus mampu memberikan nilai tambah bagi pemenuhan kebutuhan.Sepanjang unsur-unsur pidana korupsi tidak terjadi, maka proses PBJ tetap dapat dilaksanakan tanpa keraguan (Sinaga, 2018).

KPK berkomitmen mengawal pelaksanaan anggaran dan PBJ dalam rangka penanganan Covid-19. Pengawalan yang dilakukan KPK di antaranya adalah dengan membentuk tim khusus yang bekerja bersama Gugus Tugas Percepatan Penanganan Covid-19 di tingkat pusat dan daerah serta dengan pemangku kepentingan lainnya. Tim tersebut juga akan melakukan monitoring dan evaluasi terkait alokasi dan penggunaan anggaran penanganan Covid-19 agar bebas dari korupsi.

Saat ini tim sedang merampungkan untuk dapat memberikan rekomendasi terhadap persoalan sistemik yang dihadapi pelaksana di lapangan terkait pelaksanaan anggaran dan PBJ penanganan Covid-19.

D. Daftar Narahubung dan FAQ Konsultasi dalam rangka Pengadaan Barang/Jasa Darurat Covid-19 Lembaga Kebijakan Pengadaan Barang/Jasa Pemerintah

\begin{tabular}{cllc}
\hline No & \multicolumn{1}{c}{ Instansi/Wilayah } & \multicolumn{1}{c}{ Narahubung } & Nomor Telepon \\
\hline \multirow{3}{*}{1} & Kementerian/Lembaga di bawah & Dwi Satrianto & 08128006040 \\
\cline { 2 - 3 } & Kementerian Koordinator Bidang & Mirna Medita Endikasari & 08156802282 \\
& Perekonomian dan lain-lain & Mita Astari Y & 081294466960 \\
& & Anas Bayu Kusuma & 08986694949 \\
\hline 2 & Kementerian/Lembaga di bawah & Dwi Satrianto & 08128006040 \\
\hline
\end{tabular}




\begin{tabular}{|c|c|c|c|}
\hline No & Instansi/Wilayah & Narahubung & Nomor Telepon \\
\hline & Kementerian Koordinator Bidang & Fajar Adi H & 08111204915 \\
\hline & Kemaritiman dan Investasi & Sari Melani & 081280434464 \\
\hline & & Ali Masrochan & 082112523897 \\
\hline \multirow{4}{*}{3} & Kementerian/Lembaga di bawah & Selamet Budiharto & 081315186956 \\
\hline & Kementerian Koordinator Bidang Politik, & Sugianto & 081316615444 \\
\hline & Hukum dan Keamanan & Inamawati Mastuti & 081314336800 \\
\hline & & Dian Arsita W & 087884109592 \\
\hline \multirow{3}{*}{4} & Kementerian/Lembaga di bawah & Selamet Budiharto & 081315186956 \\
\hline & Kementerian Koordinator Bidang & Linda Mikowati & 081294485373 \\
\hline & Pembangunan Manusia dan Kebudayaan & Arif Budiman & 081553073785 \\
\hline \multirow{3}{*}{5} & Pemerintah Daerah & Tjipto P. Nugroho & 081330723786 \\
\hline & Wilayah Sumatera dan Banten & Imam Arumsyah & 085691095149 \\
\hline & & Astri Erviana & 087774427745 \\
\hline \multirow{3}{*}{6} & Pemerintah Daerah & Tjipto P. Nugroho & 081330723786 \\
\hline & Wilayah Kalimantan, DKI & Fajar Adi H & 08111204915 \\
\hline & Jakarta dan Jawa Barat & Ade Rizky E & 081334402989 \\
\hline \multirow{4}{*}{7} & Pemerintah Daerah & Harry S. Kahartan & 081578103560 \\
\hline & Wilayah Jawa Tengah, DI & Arif Budiman & 081553073785 \\
\hline & Yogyakarta, Bali, Nusa Tenggara Barat, & M. Dwi Sumanto & 081299436533 \\
\hline & Nusa Tenggara Timur dan Maluku & M. Taufikkurohman & 081901542667 \\
\hline \multirow{4}{*}{8} & Pemerintah Daerah Wilayah Jawa & Harry S. Kahartan & 081578103560 \\
\hline & Timur, Sulawesi dan Papua & Eben Henry R & 081298889559 \\
\hline & & Hendra D. Numberi & 081349332997 \\
\hline & & Febri Kamalisa & 081290908988 \\
\hline \multirow{3}{*}{9} & Umum/Keluhan & Mukti Herlambang & 081283454229 \\
\hline & & Makkiyah Farizqi & 08118703349 \\
\hline & & Ajeng Widi Hapsari & 081575571055 \\
\hline
\end{tabular}

\section{E. Faq pengadaan barang/jasa dalam rangka penanganan Covid-19}

\begin{tabular}{|c|c|c|}
\hline No & Pertanyaan & Jawaban \\
\hline 1 & $\begin{array}{l}\text { Siapa yang menetapkan kebutuhan } \\
\text { barang/jasa dalam rangka penanganan } \\
\text { Covid-19? }\end{array}$ & $\begin{array}{l}\text { Semua user atau pengguna barang/jasa yang membutuhkan } \\
\text { dapat mengusulkan kebutuhannya kepada PA/KPA untuk } \\
\text { ditetapkan. }\end{array}$ \\
\hline 2 & $\begin{array}{l}\text { Barang/Jasa apa yang dapat disediakan } \\
\text { melalui pengadaan dalam rangka } \\
\text { penanganan Covid-19? }\end{array}$ & $\begin{array}{l}\text { Pada prinsipnya seluruh Barang/Jasa dalam rangka } \\
\text { penanganan Covid-19 yang pemenuhan/pemanfaatannya } \\
\text { bersifat mendesak dan harus dipenuhi dalam kurun waktu } \\
\text { keadaan darurat. }\end{array}$ \\
\hline 3 & $\begin{array}{l}\text { Apakah pengadaan Barang/Jasa dalam } \\
\text { rangka penanganan Covid-19 ini dapat } \\
\text { dilaksanakan walaupun anggarannya } \\
\text { belum tersedia? }\end{array}$ & $\begin{array}{l}\text { Proses pengadaan dan pemanfaatan barang/jasa dapat } \\
\text { dilakukan walaupun anggaran belum tersedia atau tidak } \\
\text { cukup tersedia. Namun demikian, K/L/Pemda perlu } \\
\text { mengupayakan refocusing dan/atau realokasi anggaran baik } \\
\text { secara simultan ataupun setelah pelaksanaan pekerjaan. }\end{array}$ \\
\hline 4 & $\begin{array}{l}\text { Apakah pengadaan dalam rangka } \\
\text { penanganan Covid-19 dapat } \\
\text { dilaksanakan secara swakelola? }\end{array}$ & $\begin{array}{l}\text { Pelaksanaan pengadaan dalam rangka penanganan Covid- } \\
19 \text { dapat dilakukan secara swakelola oleh masing-masing } \\
\text { Kementerian/Lembaga dan Pemerintah Daerah. Dalam } \\
\text { pelaksanaan swakelola tersebut, K/L/PD dapat melibatkan } \\
\text { instansi pemerintah baik pusat maupun daerah, peran } \\
\text { serta/partisipasi lembaga nonpemerintah, organisasi } \\
\text { kemasyarakatan, masyarakat, dan/atau Pelaku Usaha. }\end{array}$ \\
\hline
\end{tabular}




\begin{tabular}{|c|c|c|}
\hline No & Pertanyaan & Jawaban \\
\hline 5 & $\begin{array}{l}\text { Apa kriteria penyedia yang ditunjuk } \\
\text { dalam penanganan } \\
\text { Covid-19? }\end{array}$ & $\begin{array}{l}\text { Kriteria penyedia yang ditunjuk adalah penyedia yang telah } \\
\text { berkontrak untuk pengadaan barang/jasa sejenis dengan } \\
\text { Instansi Pemerintah, penyedia dalam katalog elektronik, } \\
\text { penyedia pada rantai pasok terpendek (pabrikan, } \\
\text { distributor/subdistributor ataupun agen), atau penyedia lain } \\
\text { yang dianggap mampu. }\end{array}$ \\
\hline 6 & $\begin{array}{l}\text { Apakah penyedia yang diberikan uang } \\
\text { muka wajib menyerahkan Jaminan } \\
\text { Uang Muka? }\end{array}$ & $\begin{array}{l}\text { Jaminan Uang Muka tidak wajib diberikan dalam hal } \\
\text { penyedia yang ditunjuk adalah penyedia yang telah } \\
\text { berkontrak untuk pengadaan barang/jasa sejenis dengan } \\
\text { Instansi Pemerintah, penyedia dalam katalog elektronik, } \\
\text { penyedia pada rantai pasok terpendek (pabrikan, } \\
\text { distributor/subdistributor ataupun agen). }\end{array}$ \\
\hline 7 & $\begin{array}{l}\text { Apakah PPK harus memastikan } \\
\text { kewajaran harga sebelum pembayaran? }\end{array}$ & $\begin{array}{l}\text { Tidak. PPK dapat melakukan pembayaran sesuai harga } \\
\text { penawaran penyedia. Pada prinsipnya, kewajaran harga } \\
\text { merupakan tanggung jawab pihak Penyedia } \\
\text { dan bukan pihak PPK. Selanjutnya, Penyedia wajib } \\
\text { menyiapkan data/informasi dan bukti kewajaran harga } \\
\text { untuk dipertanggungjawabkan pada saat audit. }\end{array}$ \\
\hline 8 & $\begin{array}{l}\text { Apa yang dimaksud dengan bukti } \\
\text { kewajaran harga yang harus disiapkan } \\
\text { oleh Penyedia sebelum audit? }\end{array}$ & $\begin{array}{l}\text { Bukti kewajaran harga adalah dokumen yang menjelaskan } \\
\text { struktur harga penawaran yang relevan pada saat } \\
\text { pelaksanaan pengadaan, antara lain bukti pembelian dari } \\
\text { pabrikan/distributor, kontrak yang pernah dilakukan atau } \\
\text { dokumen lainnya yang dapat dipertanggungjawabkan. } \\
\text { Bukti kewajaran harga dapat juga berupa harga yang sudah } \\
\text { dipublikasikan. }\end{array}$ \\
\hline 9 & $\begin{array}{l}\text { Apakah PPK perlu menyusun HPS } \\
\text { dalam penanganan } \\
\text { Covid-19? }\end{array}$ & $\begin{array}{l}\text { Pengadaan barang/jasa dalam rangka untuk penanganan } \\
\text { Covid-19 } \\
\text { tidak }\end{array}$ \\
\hline
\end{tabular}

Apakah penyusunan spesifikasi teknis

10 barang/jasa dalam rangka penanganan

Covid-19 harus mengikuti standar

Standar Barang/Jasa yang digunakan dalam rangka penanganan Covid-19 ini pada prinsipnya disesuaikan tertentu? dengan ketentuan dari Instansi teknis yang berwenang.

$\begin{array}{lll}\text { Apakah dalam pengadaan barang/jasa } & \text { Tidak wajib, namun PPK dapat melakukan upaya } \\ \text { untuk penanganan } & \text { negosiasi atas penawaran Penyedia dengan tetap } \\ \text { Covid-19 dilakukan negosiasi teknis } & \begin{array}{l}\text { memperhatikan target waktu pemenuhan ketersediaan } \\ \text { barang/jasanya. }\end{array} & \\ \text { dan harga? } & \end{array}$
Apakah ada batasan nilai bagi PPK untuk menunjuk penyedia dalam

12 pengadaan barang/jasa penanganan Covid-

Tidak ada batasan nilai pengadaan barang/jasa, besaran nilai disesuaikan dengan kebutuhan pelaksanaan pekerjaan. 19 ?

Apakah PPK perlu mensyaratkan

13 Jaminan Pelaksanaan dalam penanganan Covid-19?

Apakah dilakukan audit pengadaan

14 barang/jasa untuk penanganan Covid19 sebelum pembayaran?

Bagaimana cara pembayaran pengadan

15 barang/jasa dalam rangka penanganan Covid-19?

16 Apakah barang/jasa dalam penanganan Covid-19 dikenakan Pajak?
Dalam rangka penanganan Covid-19 tidak diperlukan Jaminan Pelaksanaan.

Tidak. Audit pengadaan barang/jasa untuk penanganan Covid-19 dapat dilakukan setelah pembayaran.

Pembayaran dalam rangka penanganan Covid-19 dapat dilakukan secara termin atau sekaligus. Ketentuan tata cara pembayaran tersebut dituangkan dalam Surat Pesanan/SPPBJ.

Pengenaan pajak Barang/Jasa dalam rangka penanganan Covid-19 mengikuti ketentuan perpajakan yang berlaku. 


\begin{tabular}{cll}
\hline No & \multicolumn{1}{c}{ Pertanyaan } & \multicolumn{1}{c}{ Jawaban } \\
\hline \multirow{2}{*}{17} & $\begin{array}{l}\text { Bagaimana pelaksanaan serah terima } \\
\text { Barang/Jasa dalam rangka penanganan } \\
\text { Covid-19? }\end{array}$ & $\begin{array}{l}\text { Pelaksanaan serah terima Barang/Jasa dapat dilakukan } \\
\text { secara bertahap ataupun secara keseluruhan sesuai hasil } \\
\text { pelaksanaan pekerjaan. }\end{array}$ \\
\hline \multirow{2}{*}{$\begin{array}{l}\text { Apakah pengadaan Barang/Jasa dalam } \\
\text { rangka penanganan Covid-19 ini wajib } \\
\text { dilakukan secara elektronik? }\end{array}$} & $\begin{array}{l}\text { Tidak. Pengadaan dalam rangka penanganan Covid-19 ini } \\
\text { dilakukan secara manual. }\end{array}$ \\
\hline
\end{tabular}

\section{Kesimpulan}

Strategi Pengadaan Dalam Penanganan Keadaan Darurat Upaya terbaik mencapai tujuan pengadaan, dengan optimalkan mitigasi risiko yang memperhatikan aspek regulasi, justifikasi, dan data dukung/dokumentas berlandaskan prinsip dan etika pengadaan. Pengadaan barang dan jasa untuk penanganan darurat seperti sekarang dapat dilakukan dengan mekanisme penunjukan langsung dengan tahapannya mulai perencanaan, pelaksanaan pengadaan dan pembayaran

Pemerintah Sendiri untuk mengatasi pandemi ini telah mengeluarkan berbagai regulasi baik Perppu No 1 Tahun 2020 Tentang Kebijakan Keuangan Negara dan Stabilitas Sistem Keuangan untuk penanganan Covid-19, Instruksi Presiden RI No 4 Tahun 2020 Tentang Refocussing Kegiatan , Relokasi Anggaran , Serta Pengadaan Barang dan Jasa dalam rangka percepatan penanganan Covid-19, Keputusan Presiden RI No 7 Tahun 2020 Tentang Gugus Tugas Percepatan Penanganan Covid-19 dan peraturan-peraturan menteri lainnya 


\section{BIBLIOGRAFI}

Arifin, Zaenal. (2019). Rekonstruksi Pengaturan Sanggah Atas Penetapan Pemenang Tender Untuk Mewujudkan Pengadaan Barang/Jasa Pemerintah Yang Berbasis Nilai Keadilan. Universitas Islam Sultan Agung.Google Scholar

Florentina, Indri Erkaningrum, Wibowo, Alexander Jatmiko, Hoesodo, Tony S. B., Murti, Sudaru, \& Tangkas, Arya. (2020). Media, Komunikasi dan Krisis Covid-19. Penerbit Lembaga Pendidikan Sukarno Pressindo (LPSP). Google Scholar

Hamidi, Hamidi. (2020). Evaluasi Pelaksanaan Pengadaan Barang/Jasa Pemerintah dalam Mewujudkan Good Governance (Studi Penelitian di Dinas Cipta Karya dan Tata Ruang Kota Batam). EQUILIBIRIA, 7(1). Google Scholar

Harefa, Herman Jaya. (2021). Pertanggungjawaban Kepala Daerah Sebagai Pelaksana Anggaran Pendapatan Dan Belanja Daerah (Apbd) Dalam Rangka Penyelenggaraan Pemerintah Daerah Di Kota Gunungsitoli. Kumpulan Karya Ilmiah Mahasiswa Fakultas Sosial Sains, 2(02). Google Scholar

Manao, Jhohanes Jordan Tryadi. (2020). Peran Ombudsman Republik Indonesia Perwakilan Provinsi Sumatera Utara Dalam Menindaklanjuti Aduan Distribusi Bantuan Sosial Yang Menyimpang Di Kota Medan Pada Era Pandemik Covid-19. Google Scholar

Mardiyah, Rahma Ainul, \& Nurwati, R. Nunung. (2020). Dampak pandemi Covid-19 terhadap peningkatan angka pengangguran di Indonesia. Google Scholar

Purwanto, Agus, Pramono, Rudy, Asbari, Masduki, Hyun, Choi Chi, Wijayanti, Laksmi Mayesti, \& Putri, Ratna Setyowati. (2020). Studi Eksploratif Dampak Pandemi COVID-19 Terhadap Proses Pembelajaran Online di Sekolah Dasar. EduPsyCouns: Journal of Education, Psychology and Counseling, 2(1), 1-12.

Rahmad Daulay, S. T. (2021). Pergolakan Pemikiran Reformasi Birokrasi. Deepublish. Google Scholar

Ramli, Samsul. (2020). Bacaan wajib pengadaan barang/jasa penanganan keadaan darurat [sumber elektronis]. Firma KM \& Partners. Google Scholar

Rohıtan, Muhamad Arif. (2013). Tinjauan Yuridis Pengetatan Remisi DanSAatabelloksan Bersyarat Bagi Narapidana Kasus Korupsi Di Wilayah Yogyakarta. Universitas Islam Indonesia. Google Scholar

Sari, Hikmah Maya. (2021). Penerapan Protokol Pencegahan Penyebaran Corona Virus Disease 2019 (Covid-19) Pada Penyelenggaraan Proyek Konstruksi. Mecha Jurnal Teknik Mesin, 3(2), 16-22. Google Scholar

Sinaga, Yockie Veronico Amantha. (2018). Tinjauan Yuridis Pelaksanaan Kontrak Pengadaan Renovasi Gedung pada Kantor Wilayah Direktorat Jenderal Kekayaan 
Deby Triasti

Negara Sumatera Utara (Studi Kontrak Nomor Prj-1/Wkn. 02/Pbj/2018). Google Scholar

Triasti, Deby. (2021). Pengadaan Barang dan Jasa dalam Rangka Percepatan Penanganan COVID-19. Jurnal of Admiration, 2(5), 819-834. Google Scholar

Copyright holder :

Deby Triasti (2021)

First publication right :

Jurnal Syntax Idea

This article is licensed under:

(cc) (†) $\ominus$ 